\title{
Isometric Exercise, Cold Pressure Test, and Valsalva Maneuver in Subjects with Essential Hypertension and Normal Blood Pressure
}

Peter Kabo, Syukri Karim

\begin{abstract}
Abstrak
Hiperaktivitas saraf simpatis diduga merupakan salah satu penyebab hipertensi, namun penanggulangan hipertensi dengan obat antisimpatik tidak selalu memuaskan. Dengan menggunakan uji refleks autonom, yakni uji latih isometrik (isometric exercise), uji dingin (cold pressor test), dan perasat Valsalva, kami meneliti gambaran refleks autonom sebelum dan sesudah pengobatan pada 8 penderita hipertensi esensial ringan atau sedang (umur rata-rata 48, SE 2,7 tahun) tanpa komplikasi, dengan 6 sukarelawan normal (umur rata-rata 45, SE 2 tahun) sebagai kelompok kontrol. Variabel yang diukur dalam penelitian ini adalah peningkatan (dalam persen) laju jantung dan tekanan darah. Peningkatan tekanan darah pada kelompok hipertensi yang diperoleh dengan uji latih isometrik dan uji dingin lebih rendah dibandingkan dengan pada kelompok kontrol. Hal ini mungkin disebabkan karena aktivitas saraf simpatis yang berlebihan pada penderita hipertensi menyebabkan terjadinya desensitisasi baroreseptor, sehingga sulit untuk dirangsang lebih lanjut. Pada fase II dan III perasat Valsalva, takikardia (aktivitas simpatis) yang terjadi pada kelompok hipertensi lebih rendah dibandingkan pada kelompok kontrol. Sedangkan pada fase I dan IV perasat Valsalva, bradikardia (aktivitas vagus) yang timbul pada kelompok hipertensi juga lebih rendah dibanding pada kelompok kontrol. Apabila tekanan darah penderita hipertensi diturunkan dengan diet atau tiazid dosis rendah, maka terjadi penyesuaian kembali komponen simpatis, sedangkan komponen vagus tidak berubah. Karena terdapat kontrol vagus terhadap aktivitas simpatis, hasil penelitian ini menunjukkan bahwa kelemahan komponen vagus yang bertanggung jawab dalam terjadinya hipertensi, yang secara sekunder meningkatkan aktivitas simpatis.
\end{abstract}

\begin{abstract}
Sympathetic overactivity has been considered to be one of the underlying causes of hypertension; however, the management of hypertension with anti-sympathetic drugs is often unsatisfactory. By using autonomic reflex testing, i.e., isometric exercise, cold pressor test, and Valsalva maneuver, we investigated the autonomic reflex patterns before and after treatment in 8 ( $m e a n$ age 48 , SE 2.7 years) uncomplicated mild to moderate essential hypertensive patients. Six age-matched normotensive (mean age 40, SE 2 years) subjects served as a control group. Data collected in this study were the percentages of increase of heart rate and blood pressure. Percentage increase of blood pressure during isometric exercise and cold pressor test in the hypertension group was less than those in the control group. This attenuation may be due to the already overactive sympathetic nervous system in the hypertensive group causing desensitization of baroreceptors, which makes further increase of blood pressure difficult. In phases II and III of Valsalva maneuver. the percentage increase in heart rate (sympathetic activation) in the hypertensive group was less than that in the control group ( $p<0.05$ ); while in phases I and IV of Valsalva maneuver, the hypertensive group also showed a significant less decrease (vagal activation) in heart rate compared with the control group $(p<0.05)$. When blood pressure of the hypertensive group had been reduced by diet or low dose thiazide, the differences in the percentage increase of blood pressure during isometric exercise and cold pressor test, and the percentage increase in heart rate during phases II and III of the Valsalva maneuver between hypertensive group and control group were significant. However, the less decrease of heart rate in phases I and IV of Valsalva maneuver in hypertensive group was still unchanged. Since there is a vagal control of sy'mpathetic activit); this finding suggested that impairment of vagal component may be responsible for the development of hypertension, secondary to increased sympathetic activity.
\end{abstract}

Keywords: autonomic reflex testing, essential hypertension.

\section{INTRODUCTION}

Hypertension is a common disease in Indonesian community. It is reported that the prevalence of hyperten- sion in adult Indonesian ( $>20$ year-old) varies from 1.8 to $28.6 \%$.' Stroke, congestive heart failure, and coronary heart disease are the three most common complications of hypertension. There is unequivocal

National Cardiac Centers, Rumah Sakit Jantung "Harapan Kita" and Department of Cardiology, Faculty' of Medicine, University' of Indonesia, Jakarta, Indonesia 
evidence that elevation of blood pressure reduces life span. $^{2}$ Hypertension is therefore of a major concern and a hot topic in medical science. Autonomic nervous system dysfunction including an increase of sympathetic drive, ${ }^{3}$ and a decrease of vagal activity ${ }^{4}$ has been proposed to be one of the underlying cause of essential hypertension. However, treatment of hypertension is mainly focused on the inhibition of sympathetic component.

From the introduction of the very first anti-sympathetic agent, i.e., reserpine, until the latest one such as angiotensin converting enzyme inhibitors, the drugs have never been able to cure the disease; rather they only suppress the blood pressure elevation. Logically, the oversympathetic activity hypothesis on essential hypertension requires to be reviewed. The activity of autonomic nervous system is measurable through the hemodynamic changes during autonomic reflex testing such as isometric exercise, cold pressor testing, or Valsalva maneuver. ${ }^{5}$ In this study, we wish to reinvestigate the activity of sympathetic and parasympathetic nervous system in hypertensive patients based on the hemodynamic patterns of autonomic reflex testing.

\section{SUBJECTS AND METHODS}

\section{SUBJECTS}

The study group consisted of 8 patients with mild to moderate essential hypertension and 6 healthy volunteers as a control group. All patients had diastolic blood pressure values equal or exceeding $90 \mathrm{mmHg}$ on at least three measurements taken by the same investigator after the patients had been resting in the supine position for 10 minutes. Essential hypertension was defined as persistent systolic blood pressure of 140 $\mathrm{mmHg}$ or greater, or diastolic blood pressure of 90 $\mathrm{mmHg}$ or greater in the absence of secondary causes of hypertension.

The criteria for inclusion of patients were: either sex; age between 35 to 60 years old; EKG showed no myocardial infarction, left ventricular hypertrophy, or arrhythmia; no history of chronic obstructive airways disease, diabetes mellitus, or peripheral vascular disease (confirmed by chest $\mathrm{X}$-ray and complete laboratory test); no prior treatment with antihipertensive drugs, or at least has been one month discontinued using anti-hypertensive drugs.

\section{AUTONOMIC REFLEX TESTING}

After the nature of the test was explained, each subject was asked lying in a supine position in a quite room.
Three heart rates and blood pressure readings were obtained at 10 -minute intervals. The average of these measurement was designated as the resting heart rate and blood pressure.

All subjects were asked to perform autonomic reflex testing two times with 7 to 14-day interval. For hypertensive patients, after the first autonomic reflex testing, low salt diet was prescribed for 7 days. If the blood pressure did not decrease to normal (systolic blood pressure $<140 \mathrm{mmHg}$ and diastolic blood pressure $<90 \mathrm{mmHg}$ ), then they were given hydrochlorothiazide (HCT, 25-50 mg/day, maximum 7 days) until the blood pressure decreased, then the autonomic reflex testing was repeated. If the blood pressure did not decrease after treatment, the patient was excluded from the study.

\section{Isometric exercise test}

Isometric exercise was performed by squeezing a sphygmomanometer cuff at $30 \%$ of maximal grip for 2 minutes. Heart rate was measured continuously using EKG monitor. Blood pressure was measured using mercury sphygmomanometer at 1 - minute interval in the opposite arm. The maximum changes in heart rate and blood pressure were recorded.

\section{Cold pressor test}

Each subject was asked to immerse the hand to just above the wrist for 2 minutes in ice water that was kept at 4 to $5^{\circ} \mathrm{C}$. Heart rate and blood pressure were measured during the period of ice-water immersion as in isometric exercise test.

\section{Valsalva maneuver}

After obtaining the resting heart rate and blood pressure in supine position, each patient performed a Valsalva maneuver by blowing through a mouthpiece attached to a sphygmomanometer, maintaining a pressure of $40 \mathrm{mmHg}$ for 12 seconds. During the test, the surface EKG was simultaneously recorded and heart rate measured at paper speed of $25 \mathrm{~mm} / \mathrm{sec}$. The Valsalva maneuver was divided in four phases: ${ }^{6}$ In phase I heart rate as the lowest heart rate immediately after straining was initiated. In phase II heart rate as the fastest heart rate at the end of the straining period. The phase III heart rate as the maximum rate just following release. The phase IV heart rate as the lowest heart rate observed after release. 


\section{STATISTICS}

Data are presented as means and standard errors of the means. The statistical significance of difference between pairs of means was determined by unpaired Student's $t$ test. The relationship between two variables was calculated by Pearson product moment correlation coefficient. The analysis were performed using computer program CSS (Statsoft, Tulsa, USA) run under the NS-DOS 3.3 operating system. In all cases levels of probability $(p)$ of less than 0.05 were taken to indicate significance.

\section{RESULTS}

The basic characteristics of 8 hypertensive patients and 6 healthy volunteers as a control group are shown in Table 1. There were no significant difference in age and height between groups, although the body weight of hypertensive patients tended to be higher than the healthy volunteers.

Table 1. Basic characteristics of age, body weight, height, resting heart rate (HR), systolic blood pressure (SBP), diastolic blood pressure (DBP) between 8 hypertensive patients and 6 healthy volunteers.

\begin{tabular}{lccc}
\hline & $\begin{array}{c}\text { Hypertension } \\
n=8\end{array}$ & P & $\begin{array}{c}\text { Control } \\
n=6\end{array}$ \\
\hline Age (years) & $48 \pm 2.7$ & NS & $45 \pm 2$ \\
Sex (Male) & 7 & & 5 \\
$\quad$ (Female) & 1 & & 1 \\
HR (Beats/min) & $74 \pm 2.3$ & NS & $68.7 \pm 3.1$ \\
SBP (mmHg) & $162.5 \pm 4.3$ & S & $123 \pm 4$ \\
DBP (mmHg) & $99.5 \pm 2.1$ & S & $78.3 \pm 2.7$ \\
Weight (kg) & $62.1 \pm 3.5$ & NS & $57.1 \pm 3.2$ \\
Height (cm) & $161 \pm 3.1$ & NS & $158 \pm 3.2$ \\
\hline
\end{tabular}

\section{Isometric exercise test}

Figure 1 shows the percentage increase of systolic blood pressure (SBP), diastolic blood pressure (DBP), and heart rate (HR) during isometric test for 8 hypertensive patients and 6 healthy volunteers. In healthy volunteers, the percent increase of SBP was 33.5
$\mathrm{mmHg}$ (SE 43.1), DBP was $29.5 \mathrm{mmHg}$ (SE 4.5), HR was 27.3 per minute (SE 3.3). There was no statistically significant difference in the first test compared to the second test $(p>0.05)$. In hypertensive patients, the percentages increase of SBP, DBP, and HR were less than those in the healthy volunteers; i.e., $20 \mathrm{mmHg}$ (SE 2.7), $22 \mathrm{mmHg}$ (SE 3.4), and 25.5 per minute (SE 2.5), respectively. After receiving low salt diet or HCT treatment, these values could reach the same level as in healthy volunteers. In all subjects, the percentages increase of SBP and DBP were negatively correlated to the resting SBP and DBP (Figures 2 and 3 ).

\section{Cold pressure test}

Figure 4 shows the percentage increase of SBP, DBP, and HR during cold pressor test for 8 hypertensive patients and 6 healthy volunteers. In healthy volunteers, the percent increase of SBP was $35.2 \mathrm{mmHg}$ (SE 7.4), DBP was $30.5 \mathrm{mmHg}$ (SE 6.0), and HR was 16.8 per minute (SE 4.1). There were no significant differences in the first test compared to the second test ( $p>0.05$ ). In hypertensive patients, the percentage increase of SBP, DBP, and HR were again less than the healthy volunteers, i.e., $21.9 \mathrm{mmHg}$ (SE 3.3), 22.5 $\mathrm{mmHg}$ (SE 3.1), and 20.0 per minute (SE 3.4), respectively. After receiving low salt diet or HCT treatment, these values could reach the same level as in healthy volunteers. In all subjects, the percentage increase of SBP and DBP were negatively correlated with the resting $\mathrm{SBP}$ and $\mathrm{DBP}$, respectively.

\section{Valsalva maneuver}

The percentage heart rate changes from resting during each phase of Valsalva maneuver in 8 hypertensive patients and 6 healthy volunteers are shown in Figure 5. In 6 healthy volunteers, there was no significant difference between phase I, II, III, and IV of the first and second Valsalva maneuver $(\mathrm{p}>0.05)$. In hypertensive patients, the bradycardia in phase I and IV, as well as tachycardia in phases II and III were less than in those healthy subjects $(p<0.05)$, i.e., -0.3 (SE (2.1), -4.75 (SE 1.53), 26.5 (SE 3.95), and 30 per minute (SE 4.2 ), respectively. After receiving low salt diet or HCT treatment, the percentage HR increase in phases II and III could reach the same level as in healthy volunteers, i.e., 44.5 (SE 3.8), and 46.7 per minute (SE 3.8), respectively. However, the vagal mediates bradycardia in phases I (-1.1, SE 1.7) and phase IV (-3.95, SE 1.1) were unchanged. 


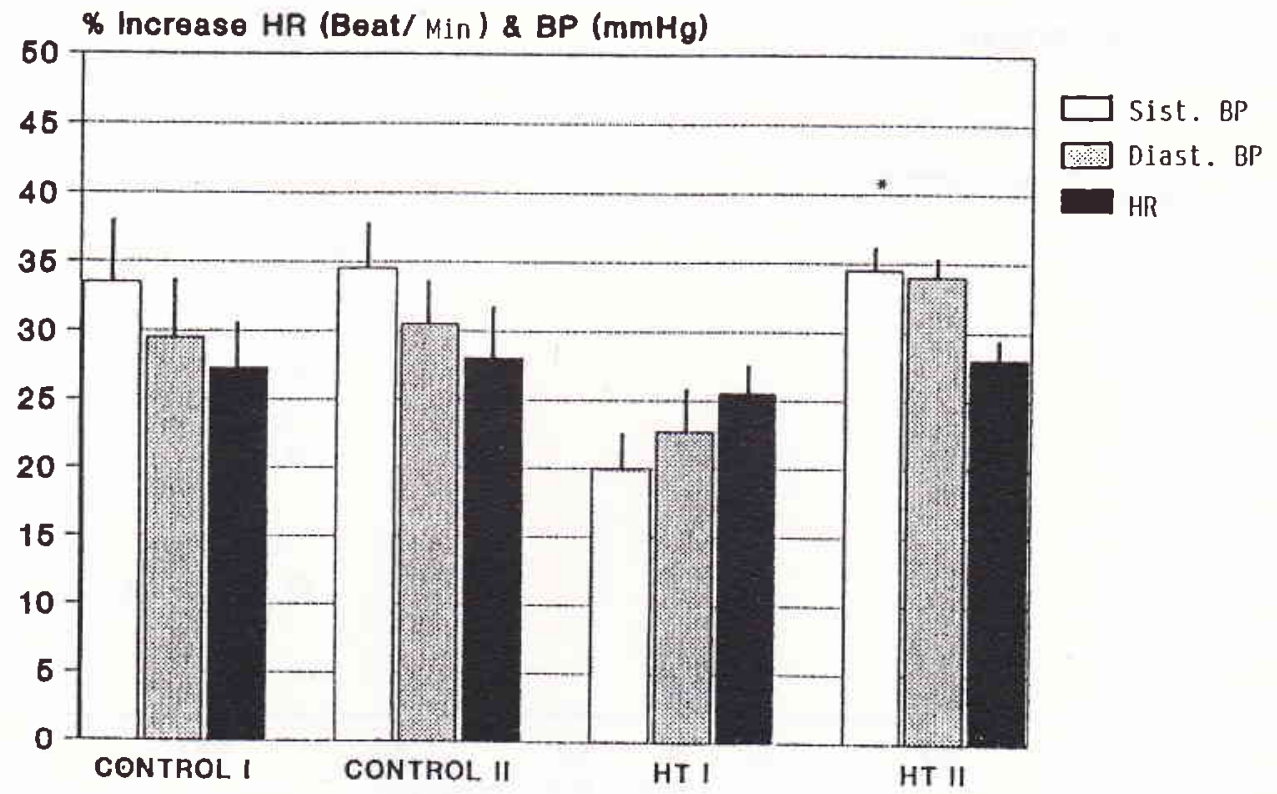

Figure 1. Isometric exercise test.

Percent of heart rate (HR), systolic blood pressure (Syst. BP), and diastolic blood pressure (Diast. BP) increase during isometric exercise test in 6 control subjects (Control) and 8 hypertensive patients (HT). Control I and II = the first and second test of control subjects. HT I and $I I=$ the first (before treatment) and second (after treatment)
test of hypertensive patients.

* indicates a significant difference from the first test $(P<0.05$; paired $t$-test $)$.

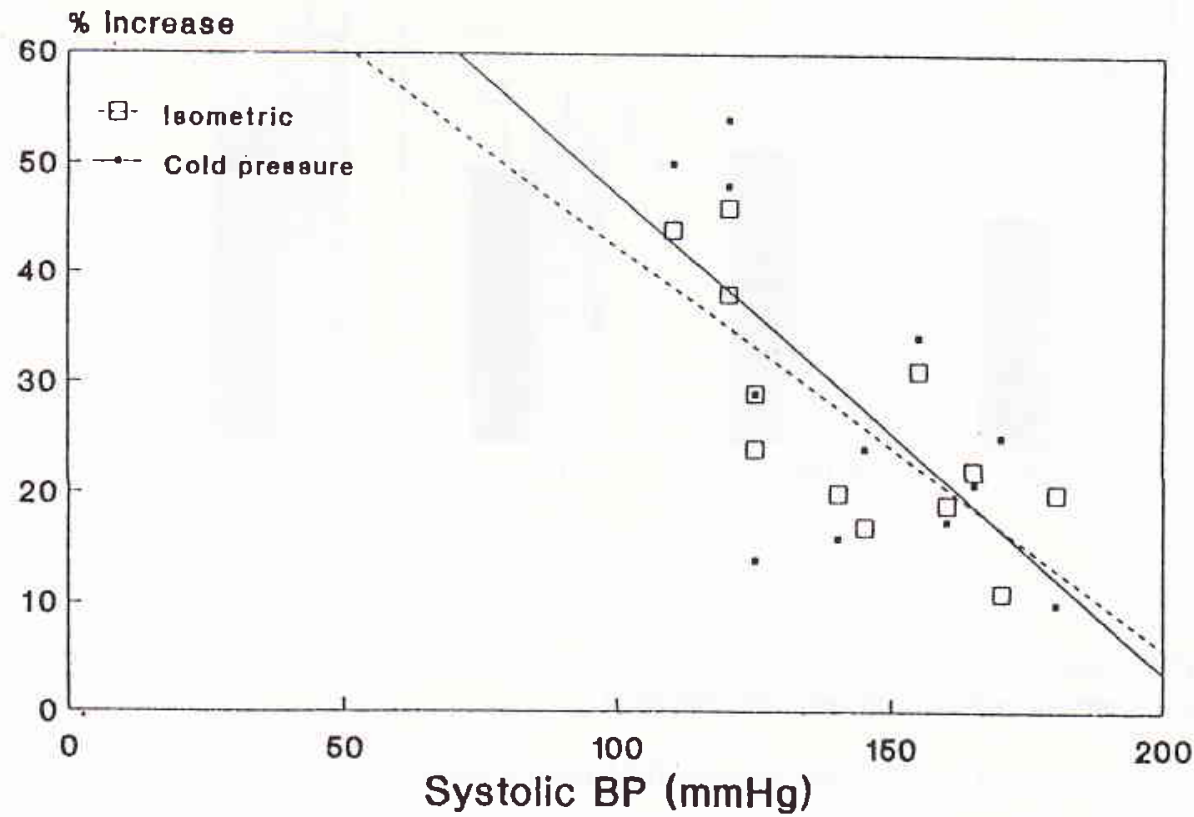

Figure 2. Correlation of \% increase \& systolic BP. 


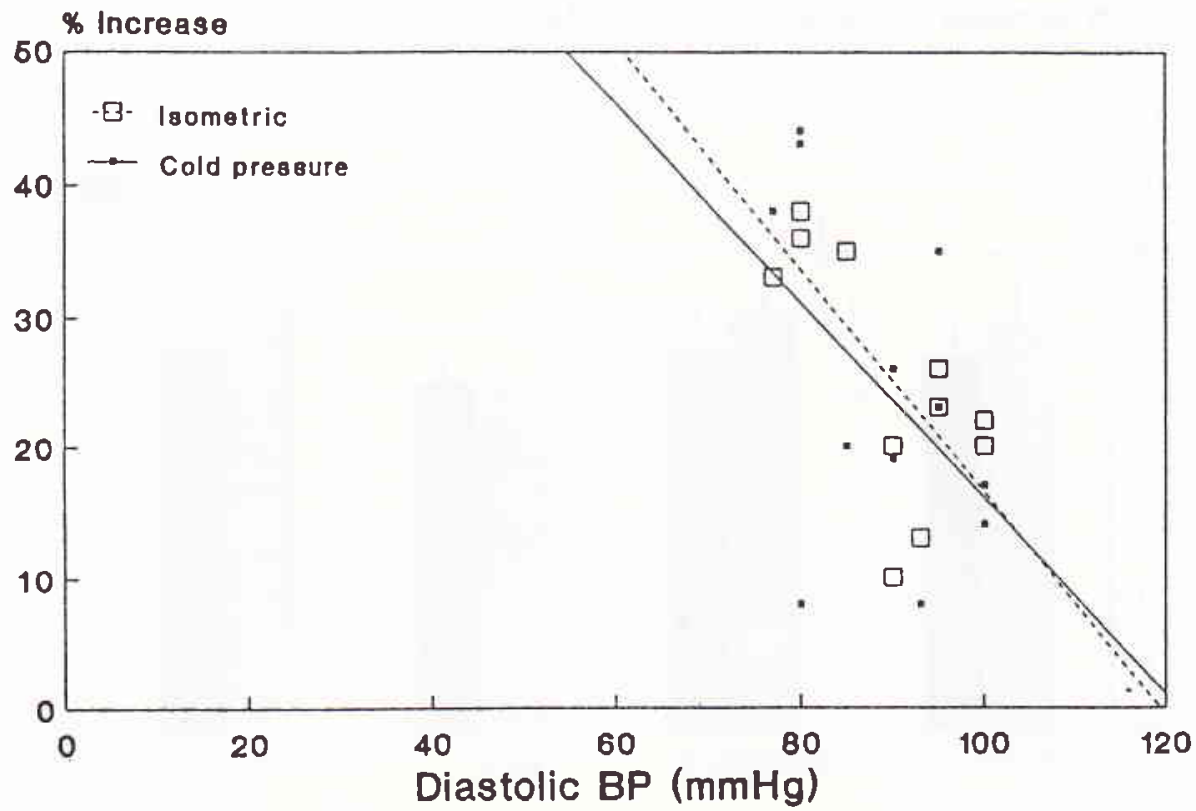

Figure 3. Correlation of $\%$ increase \& diastolic BP.

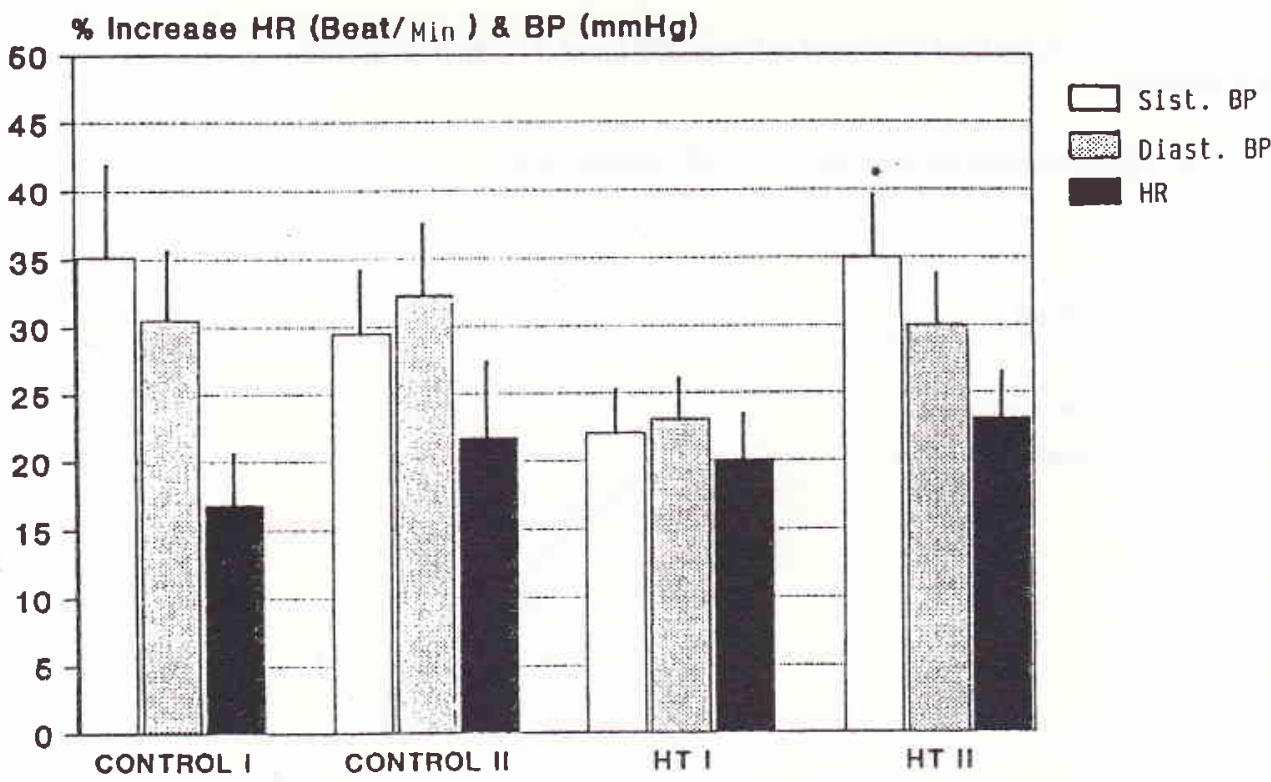

Figure 4. Cold pressure test.

Percent of heart rate (HR), systolic blood pressure (Syst. BP), and diastolic blood pressure (Diast. BP) increase during cold pressor test in 6 control subjects (Control) and 8 hypertensive parients (HT).

Control I and II = the first and second test of control subjects. HTI and II = the first (before treatment) and second (after treatment) test of hypertensive patients.

* indicates a significant difference from the first test $(P<0.05$; paired $t$-test $)$. 


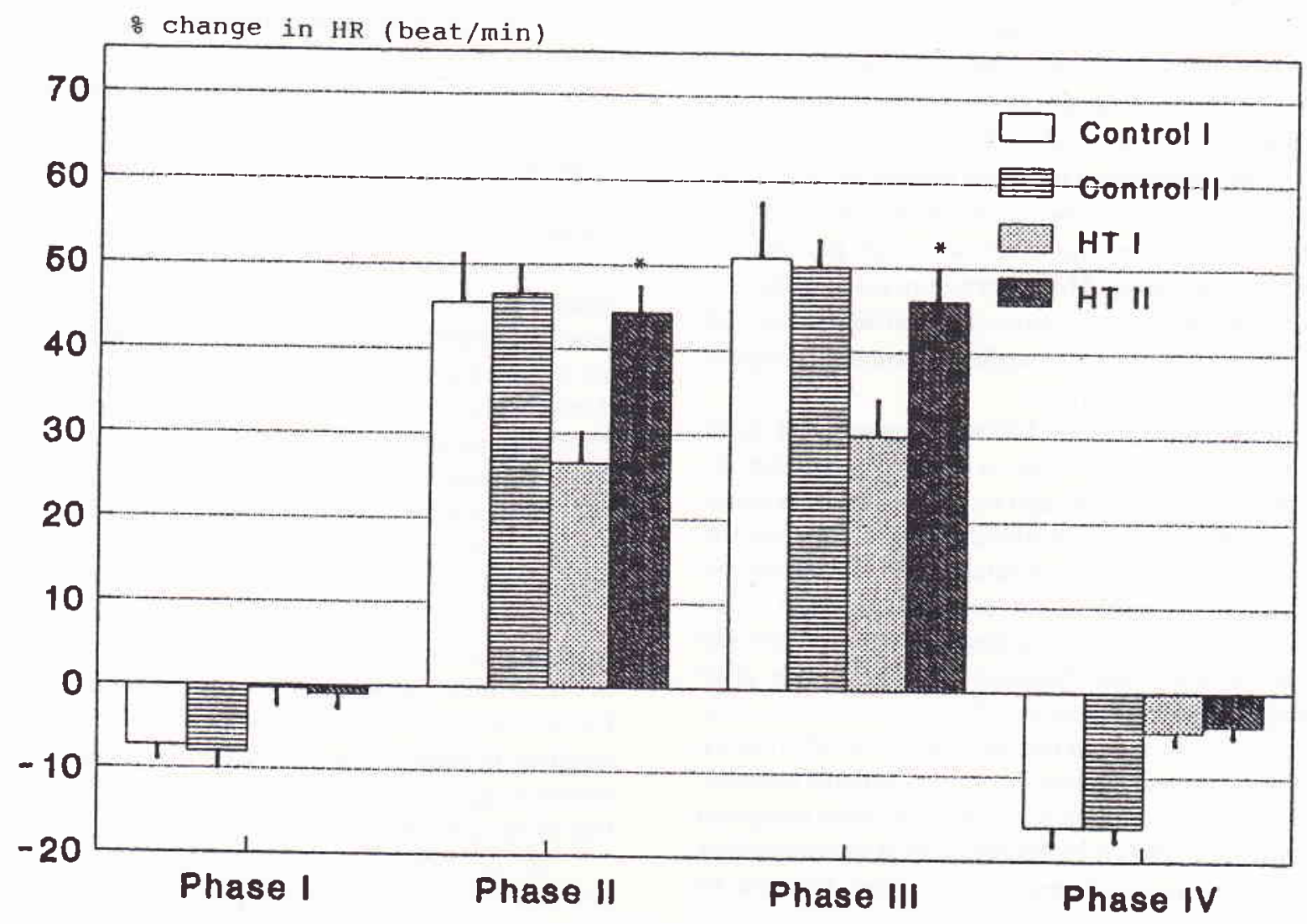

Figure 5. Valsava maneuver.

Percent of heart rate changes (mean \pm s.e.m.) during the 12 seconds of Valsalva monoeuvre in 6 control subjects (Control) and 8 hypertensive patients (HT).

* indicates significant difference from the first test.

\section{DISCUSSION}

It has long been known that during isometric contraction $^{7}$ and cold stimulus ${ }^{8}$ there is an activation of receptor in the muscle producing rise of blood pressure and heart rate mediated through a neurogenic sympathetic reflex arc. This was confirmed by present results; during isometric exercise and cold pressor test, there were increase in heart rate and blood pressure in all subjects, and the results were reproducible.
If the increases in heart rate and blood pressure were converted as a percentage of resting heart rate and blood pressure; the percentage increase were negatively correlated to the resting heart rate and blood pressure (see Figures 2 and 3). Thus, normal subjects tended to have higher percentage increase in heart rate and blood pressure compared with hypertensive patients. This finding is unexpected since it has been demonstrated that hypertensive patients often have an increased heart 
rate response to isoprenaline more than in normal subjects because of the hyperdynamic beta-adrenergic state. ${ }^{9}$ However, it has also been shown that in hypertensive patients there is an increase of catecholamine release, ${ }^{10}$ causing desensitization of cardiopulmonary and baro-reflex control of heart rate and blood pressure. 1 This impairment has been termed as 'resetting' of cardiac receptor following the development of hypertension. Whether the attenuation of percent increased in heart rate and blood pressure in hypertensive patients during isometric exercise or cold pressor test is cause by resetting of cardiopulmonary receptors needs further investigations.

Interestingly, when blood pressure had been decreased by low salt diet or hydrochlorothiazide, which was not acting through receptor sites, and therefore may not alter the hyperdynamic reflex pattern, the percentage increase in heart rate and blood pressure in hypertensive patients could return to normal. This mean that the desensitization stage of cardiopulmonary and baro-reflex could become sensitive again after lowering the blood pressure (Figures 1 and 4 ). This finding may indicate that the increase of blood pressure stimulates increase, or may further stimulates increase of sympathetic tone, which in turn stimulates receptors desensitization. When blood pressure is decreased (by diet or drugs), the sympathetic tone follows to decrease, resulting a reverse sensitivity of arterial baroreceptors.

The Valsalva maneuver is divided into 4 phases, ${ }^{6}$ the mechanisms are as follows: ${ }^{11}$ Phase 1 is the period of brief bradycardia at the onset of straining. The sudden increase in intrathoracic pressure associated with strain is transmitted to peripheral arterial vessels; the sudden increase in arterial pressure stimulates arterial baroreceptors and vagal reflex slows the heart rate. Phase 2 is the continued steady increase in intrathoracic pressure during sustained strain. As volume builds up in the extrathoracic veins, the cardiac output falls. This is accompanied by increase in heart rate as a result of sympathetic stimulation. Phase 3 is the sudden loss of support of intrathoracic pressure at the sudden release of strain, and induces further sympathetic stimulation and increase in heart rate. Phase 4 is the drop of intrathoracic pressure in the period after release of strain. This causes blood which is dammed out the venous system to rush back into the heart. The sudden increase of blood filling to the heart is then pumped into the constricted peripheral system, an overshoot of blood pressure again causing vagally mediated reflex bradycardia.

In accord with the results of isometric exercise and cold pressor tests, the percent increase of heart rate during phases II and III of Valsalva maneuver (which involved sympathetic activation) in hypertensive patients is less compared with that in normal subjects. This may be due to the already increase of sympathetic activity in hypertension causing baroreceptor desensitization as mentioned above. On the other hand the parasympathetic activity is decreased in hypertensive patients. In which, stimulation of this system during phases I and IV of Valsalva maneuver would not further decrease heart rate; as the result, the percent decrease of heart rate in hypertensive patients is smaller compared to that in normal subjects. This was not surprising since previous studies have shown that there were hyperdynamic beta-adrenoceptor and decreased parasympathetic tone in hypertension. ${ }^{12}$

Of particular interest was that after blood pressure had been revised, why only the sympathectic component returned to normal leaving vagal component unchanged? It has been demonstrated that acethylcholine release from cholinergic nerve terminal may activate muscarinic receptor located on noradrenergic nerve terminal, which inhibits noradrenaline release. ${ }^{13}$ Furthermore, it has been shown that there is acetylcholine release from sympathetic nerve. ${ }^{14}$ These results suggested that there is cholinergic system control of sympathetic pathway.

If the activity of cholinergic control system decrease, then there is an increase of sympathetic traffic, causing an increase vascular responsiveness and blood pressure elevation. High blood pressure may further stimulate cathecolamine release. The mechanism behind this is unclear, whether it involves positive feedback mechanism ${ }^{15}$ or other mechanism needs further investigation.

Nevertheless, it is perhaps that the disturbance of autonomic nervous system responsible for blood pressure elevation is the defect of basal vagal regulatory control function. This finding would be a future recommendation for management of high blood pressure that increasing the vagal component, rather than inhibiting the sympathetic component may be a more appropriate approach.

\section{REFERENCES}

1. Darmojo RB. Data epidemiologi hipertensi di Ineonesia. Dalam: Rukmono B, Sulistio E: Hipertensi - pendekatan praktis dan penatalaksanaan. Jakarta; 1986.

2. Morgan TO. High blood pressure. Whom to investigate? Whom to trea? In: Managing Blood pressure. National Health Foundation of Australia. 1990:4-7.

3. Okamoto K, Suzuki A, Sunano S. Alteration of sympathetic transmission and vascular muscle reactivity in spontaneous hypertension. In: Progress in hypertension. Vol. 1. Eds: $\mathbf{H}$ Saito, H Parvez, S Parvez, T Nagatsu. Utrecht, 1988: 47-63. 
4. Julius S, Esler M. Autonomic nervous cardiovascular regulation in borderline hypertension. Am J Cardiol 1975; 36:68596.

5. Ewing DJ, Hume L, Campbell IW, Murray A, Neilson JMM, Clarke BF. Autonomic mechanisms in the initial heart rate response to standing. J App Physiol 1980; 49:809-14.

6. Kalbfleisch JH, Stowe DF, Smith JJ. Evaluation of the heart rate response to the Valsalva maneuver. Am Heart J 1978; 95:707-15.

7. Shepherd JT. Circulatory response to exercise in health. Circulation 1987; 76 (Suppl. VI): VI.3-VI.10.

8. Wood DL, Sheps SG, Elveback LR, Schirger A. Cold pressor test as a predictor of hypertension. Hypertension 1984; 6:301-6.

9. Messerli FH. Pathophysiologic clinical clues in essential hypertension: a rationale for initial therapy. J Cardiovase Pharmacol 1984; 6:S528-34.
10. Westfall TC, Meldrum MJ. Alterations in the release of norepinephrine at the vascular neuroeffector junction in hypertension. Ann Rev Pharmacol Toxicol 1985;25:621-41.

11. Shepherd JT, Mancia G. Reflex control of the human cardiovascular system. Rev Physiol Biochem Plıarnacol 1986; 105:1-99.

12. Julius S. Autonomic nervous dysfunction in essential hypertension. Diabetes Care 1991;14:249-59.

13. Kalsner S, Quillan M. Presynaptic interactions between acetylcholine and adrenergic antagonists on norepinephrine release. J Pharmacol Exp Ther 1988;24: 879-91.

14. Bowman WC, Rand MJ. Textbook of pharmacology. Second Edition, Chapter 11. Blackwell Scientific Publications, Oxford, 1982.

15. Langer SZ. Presynaptic regulation of cathecholamine release. Biochem Pharmacol 1974; 23:1793-800. 